A N N A L E S

UNIVERSITATIS MARIAE CURIE-SKŁODOWSKA LUBLIN - POLONIA

VOL. LXXI, z. 1

SECTIO B

2016

1Zakład Ochrony Środowiska UMCS; wkalamuc@umcs.pl

${ }^{2}$ Zakład Racjonalnego Użytkowania Zasobów Naturalnych i Ochrony Przyrody

Uniwersytet Iwana Franki we Lwowie; pavlotelish@i.ua

WIOLETTA KAŁAMUCKA ${ }^{1}$, PAVLO TELISH ${ }^{2}$

\title{
Razem i osobno. Obszary chronione na pograniczu województwa lubelskiego i obwodu lwowskiego
}

Together and separately.

Protected areas on the borderline of Lublin Voivodeship and Lviv Oblast Slowa
lwowski

Keywords: nature protection, state border, Lublin Voivodeship, Lviv Oblast

\section{WPROWADZENIE}

Województwo lubelskie, położone przy granicy Polski i jednocześnie na peryferiach Unii Europejskiej, stanowi obecnie bardzo ważny obszar kształtowania się procesów integracji europejskiej obejmujących różne dziedziny działalności, począwszy od polityki, przez gospodarkę, aż do sfery szeroko pojętej kultury. Naturalnym polem współpracy jest ochrona przyrody i środowiska. W tej części Europy powojenne granice przecięły wiele jednostek przyrodniczych różnych kategorii. Zarówno gospodarowanie, jak i działalność na rzecz ochrony przyrody na ich obszarze kształtować się musiały w odmiennych warunkach prawnych i społecznych i dały różne efekty. Najcenniejsze przyrodniczo obszary pogranicza polsko-ukraińskiego tworzą charakterystyczny układ, w którym na obrzeżach znajdują się unikalne przyrodniczo Polesie Zachodnie i Bieszczady, a w części środkowej wyjątkowy region Roztocza. Ochrona przyrody na tych obszarach jest przykładem owocnej współpracy sąsiadujących państw. Przyniosła ona, mimo różnie kształtowanej polityki ochrony przyrody, powołanie dwóch trójstronnych, transgranicznych rezerwatów biosfery UNESCO - Polesie Zachodnie (Polska-Ukraina-Białoruś) i Beskidy Wschodnie (Polska-Słowacja-Ukraina) oraz 
nadzieję na powstanie Transgranicznego Rezerwatu Biosfery Roztocze - wniosek w tej sprawie złożono w 2015 roku. Zaznaczyć należy, że Polska i Ukraina są jedynymi krajami na świecie, na pograniczu których utworzono dwa trójstronne rezerwaty biosfery. W ich strefie przygranicznej występują wszystkie wielkoobszarowe formy ochrony i niemal wszystkie formy ochrony o znaczeniu lokalnym, jakie przewidują systemy prawne obu krajów. W artykule zostanie przedstawiony zarys działań na rzecz ochrony przyrody oraz stan ochrony obszarowej na pograniczu województwa lubelskiego i obwodu lwowskiego. Do analizy wybrano obszary wielkopowierzchniowe sąsiadujące z granicami państwowymi oraz drobne formy ochrony w odległości mniejszej niż $10 \mathrm{~km}$ od nich.

\section{WSPÓLNA HISTORIA}

Ochrona omawianego obszaru ma wielowiekową tradycję (Brusak 2000; Wachniewska 1959). Szczególne nasilenie działalności ochroniarskiej miało miejsce w XIX wieku w okresie zaborów. W różnych kręgach społeczeństwa, wśród naukowców, publicystów, nauczycieli, działaczy towarzystw społecznych, duchowieństwa, uformował się szeroki nurt społeczny na rzecz ochrony przyrody. W nieistniejącej wówczas na mapie politycznej Europy Polsce ochrona przyrody ojczystej stała się sposobem na zachowanie tożsamości narodowej. Motywy patriotyczne i społeczny charakter pracy na rzecz ochrony przyrody były gwarancją działań na najwyższym poziomie, traktowanych jako służba ojczyźnie. Po zakończeniu I wojny światowej w niepodległej Polsce istniało już 39 małych rezerwatów przyrody. Najstarszym była Pamiątka Pieniacka, utworzona przez Wojciecha Dzieduszyckiego w jego majątku na Podolu (Szafer 1965).

Duże zaangażowanie elit społecznych przyczyniło się do rozpoczęcia działań na rzecz ochrony przyrody niemal natychmiast po uzyskaniu niepodległości. W 1919 roku ukonstytuowała się Państwowa Rada Ochrony Przyrody, przystąpiono do tworzenia kolejnych rezerwatów, pomników przyrody. Treści związane z ochroną przyrody wprowadzano do edukacji na wszystkich poziomach, organizowano seminaria biocenotyczne i ochrony przyrody, będące forum wymiany poglądów specjalistów z zakresu biologii, leśnictwa, rolnictwa, prawników, ekonomistów, lekarzy, przedstawicieli prasy, artystów, studentów i innych zainteresowanych tą tematyką. W 1934 roku uchwalono nowoczesną, jak na owe czasy, ustawę o ochronie przyrody (Dz.U. $1934 \mathrm{nr}$ 31, poz. 274).

Biorąc pod uwagę aktywność w zakresie ochrony przyrody w okresie międzywojennym, należy stwierdzić, że najwyższa była ona na ziemi lwowskiej. Lwów był ważnym ośrodkiem naukowym, dzięki temu utworzono tu oddział Państwowej Rady Ochrony Przyrody (mającej główną siedzibę w Krakowie). Zajmował się on m.in. typowaniem obiektów przyrodniczych do ochrony na podległym mu obszarze. Liczba spraw rozpatrywanych przez oddział lwowski 
(jeden z czterech, jakie powołano) była bardzo duża. W latach 1920-1936 wynosiła 4177, podczas gdy w oddziale warszawskim 647, a w wileńskim 288 (Szafer 1965). Obszar województwa lubelskiego podlegał oddalonym znacznie oddziałom we Lwowie i Warszawie, co nie sprzyjało aktywności w tej dziedzinie. Tworzenie obszarów chronionych na Lubelszczyźnie związane było w znacznej mierze z działalnością Ordynacji Zamojskiej na Roztoczu. W okresie międzywojennym na terenach obecnego województwa lubelskiego utworzono rezerwaty leśne: na południu w Ordynacji Zamojskiej rezerwat Bukowa Góra, a na północy oraz w okolicach Łukowa rezerwaty Jata i Topór.

\section{WARUNKI OCHRONY PRZYRODY W POLSCE PO II WOJNIE ŚWIATOWEJ}

Po zakończeniu wojny działalność na rzecz ochrony przyrody w Polsce kontynuowano w nowych granicach zarówno na terenie kraju, jak i na forum międzynarodowym. Polska była aktywnym członkiem-założycielem Międzynarodowej Unii Ochrony Przyrody od 1949 roku, a prof. Władysław Szafer jej członkiem honorowym. Podkreślić należy ogromną rolę Polaków w tworzeniu nowej wizji ochrony przyrody. W dyskusji ścierały się różne koncepcje ochrony: tradycyjna, konserwatorska - polegająca na ochronie pojedynczych obiektów i tworów przyrody, i nowoczesna - polegającą na aktywnej ochronie dużych obszarów o zróżnicowanych reżimach ochronnych. Polacy wraz ze Szwajcarami, Holendrami i Bułgarami przekonali członków IUCN, że należy podążyć drugą drogą. W efekcie tej decyzji i rozwoju obszarów chronionych powierzchnia objęta ochroną w skali świata to ok. 209 tys. obszarów chronionych (PAS), obejmujących 15,4\% terenów lądowych i wód śródlądowych oraz 3,4\% oceanów (Protected Planet Report, 2014); Polska znalazła się wśród krajów przodujących w tworzeniu wielkoobszarowych form ochrony.

Pierwsze działania na rzecz ochrony przyrody w Polsce powojennej oparte były jeszcze na przepisach ustawy o ochronie przyrody z 1934 roku, a od 1949 roku wzorowanej na niej nowej ustawie o ochronie przyrody (Dz.U. $1949 \mathrm{nr}$ 25, poz. 180). Druga połowa lat siedemdziesiątych przyniosła powstanie pierwszych obszarów chronionych o znacznych powierzchniach: parków krajobrazowych oraz obszarów chronionego krajobrazu. Ich powołanie było wynikiem indywidualnie podejmowanych inicjatyw właściwych samorządów. W 1980 roku wprowadzono przepisy umożliwiające tworzenie nowych wielkoobszarowych form ochrony, którymi były parki krajobrazowe i obszary chronionego krajobrazu. W 1991 roku kolejna ustawa o ochronie przyrody wprowadzała formy ochrony o znaczeniu lokalnym, które można było tworzyć na podstawie uchwał władz najniższego szczebla (Dz.U. 1991 nr 114, poz. 492). Były to: użytki ekologiczne, zespoły przyrodniczo-krajobrazowe, stanowiska dokumentacyjne (Simonides 2007). 
Przystąpienie Polski do Unii Europejskiej wymagało przystosowania w tym zakresie prawa, m.in. wprowadzenia unijnej sieci obszarów chronionych Natura 2000, obowiązującej we wszystkich państwach członkowskich Unii. Zapisy uwzględniające nową sytuację znalazły się w obecnie obowiązującej ustawie z 2004 roku. Ustawa wprowadza 10 form ochrony przyrody. Są to: park narodowy, rezerwat przyrody, park krajobrazowy, obszar chronionego krajobrazu, obszar Natura 2000, użytek ekologiczny, stanowisko dokumentacyjne, zespół przyrodniczo-krajobrazowy, pomnik przyrody oraz ochrona gatunkowa roślin i zwierząt (Dz.U. $2004 \mathrm{nr}$ 92, poz. 880).

\section{STAN OCHRONY W WOJEWÓDZTWIE LUBELSKIM}

Do II wojny światowej województwo lubelskie mimo to, że położone było w centralnej części Polski było słabo rozpoznane pod względem przyrodniczym. Dopiero powstanie w Lublinie w 1944 roku Uniwersytetu Marii Curie-Skłodowskiej, który tworzyło wielu wybitnych naukowców z zakresu nauk przyrodniczych, w znacznej części ze Lwowa, przyczyniło się do rozpoznania zasobów środowiska i krajobrazu Lubelszczyzny oraz stopniowego obejmowania ochroną najcenniejszych jego części. Obecnie na terenie województwa ochroną objęto $5702,8 \mathrm{~km}^{2}$, to jest $22,7 \%$ powierzchni województwa (GUS, 2014). Jest to proporcjonalnie mniej niż w Polsce, gdzie wartość ta wynosi 32,8\%. Ze względu na niższą gęstość zaludnienia powierzchnia przypadająca na 1 osobę w województwie jest niemal taka jak średnia krajowa i wynosi $2644 \mathrm{~m}^{2}$. Powierzchnię objętą ochroną oraz liczbę obiektów chronionych w województwie lubelskim na tle Polski przestawia tabela 1 .

\section{WARUNKI KSZTAŁTOWANIA SIĘ SIECI OBSZARÓW CHRONIONYCH W OBWODZIE LWOWSKIM}

Po II wojnie światowej obszar obecnego obwodu lwowskiego (o powierzchni $21833 \mathrm{~km}^{2}$ ) należał do Związku Radzieckiego, gdzie zagadnienia ochrony przyrody i krajobrazu przez długi czas traktowano marginalnie (Herenczuk, Stoyko 1976; Stoyko 1992). Niektóre działania na rzecz ochrony dokonywały się w sposób niezamierzony, na przykład utworzenie poligonu wojskowego w okolicach Jaworowa jako terenu zamkniętego przyczyniło się do zachowania walorów przyrodniczych tego obszaru. W latach siedemdziesiątych i osiemdziesiątych w sytuacji wzrostu znaczenia ochrony przyrody w skali ogólnoświatowej zaczęto obejmować ochroną niektóre obszary obwodu o większych powierzchniach, tworząc rezerwaty: Grzęda, Zawadowski, Czartowska Skała, Lwowski, Winnikowski. Ważnym wydarzeniem w historii ochrony tego obszaru było utworzenie w 1984 roku rezerwatu przyrody Roztocze, korzystając $\mathrm{z}$ istniejących form ochrony: 
Tab. 1. Formy ochrony przyrody w Polsce i w województwie lubelskim w 2013 roku

Tab. 1. Forms of nature conservation in Poland and Lubelskie Voivodeship in 2013

\begin{tabular}{|c|c|c|c|c|c|}
\hline \multirow[b]{2}{*}{$\begin{array}{l}\text { Formy ochrony } \\
\text { Forms of nature } \\
\text { conservation }\end{array}$} & \multicolumn{2}{|c|}{$\begin{array}{l}\text { Polska } \\
\text { Poland }\end{array}$} & \multicolumn{3}{|c|}{$\begin{array}{l}\text { Województwo lubelskie } \\
\text { Lubelskie Voivodeship }\end{array}$} \\
\hline & $\begin{array}{l}\text { Liczba } \\
\text { Number }\end{array}$ & $\begin{array}{c}\text { Powierzchnia } \\
\text { w ha } \\
\text { Area (ha) }\end{array}$ & $\begin{array}{l}\text { Liczba } \\
\text { Number }\end{array}$ & $\begin{array}{c}\text { Powierzchnia } \\
\text { w ha } \\
\text { Area }(h a)\end{array}$ & $\begin{array}{c}\text { Udział } \\
\text { w powierzchni } \\
\text { chronionej } \\
\text { w Polsce }(\%) \\
\text { Share in nature } \\
\text { conservation areas } \\
\text { in Poland }(\%)\end{array}$ \\
\hline Parki narodowe & 23 & 314684,46 & 2 & 18243,11 & 5,8 \\
\hline Rezerwaty przyrody & 1480 & 165732,76 & 87 & 11862,90 & 7,2 \\
\hline Parki krajobrazowe & 122 & 2606038,52 & 17 & 241182,00 & 9,3 \\
\hline $\begin{array}{l}\text { Obszary chronionego } \\
\text { krajobrazu }\end{array}$ & 385 & 7096928,97 & 17 & 301970,80 & 4,3 \\
\hline $\begin{array}{l}\text { Obszary Natura } 2000 \\
\text { (ptasie) }\end{array}$ & 145 & 4910074,00 & 23 & 335841,20 & 6,8 \\
\hline $\begin{array}{l}\text { Obszary Natura } 2000 \\
\text { (siedliskowe) }\end{array}$ & 849 & 3456316,10 & 100 & 164724,07 & 4,7 \\
\hline Użytki ekologiczne & 162 & 51843,71 & 7 & 7025,84 & 13,6 \\
\hline $\begin{array}{l}\text { Stanowiska } \\
\text { dokumentacyjne }\end{array}$ & 7090 & 904,97 & 265 & 11,30 & 1,2 \\
\hline $\begin{array}{l}\text { Zespoły } \\
\text { przyrodniczo-krajo- } \\
\text { brazowe }\end{array}$ & 331 & 95869,89 & 7 & 768,80 & 0,8 \\
\hline Ogółem & $\mathrm{x}$ & 10165112,01 & $\mathrm{x}$ & 570282,95 & 5,6 \\
\hline
\end{tabular}

Źródło: Opracowanie własne na podstawie Ochrona środowiska 2014 i http://natura2000.gdos. gov.pl/strona/natura-2000-w-polsce

Source: own study based on Ochrona środowiska 2014 and http://natura2000.gdos.gov.pl/ strona/natura-2000-w-polsce

botanicznego pomnika przyrody Horbki i Stawki, rezerwatu Stradczański Las, uroczyska Królewska Góra. Od lat dziewięćdziesiątych obserwuje się wzrost powierzchni obszarów chronionych, m.in. parków krajobrazowych. Powołano je najpierw w zachodniej części Ukrainy. Pierwszy park krajobrazowy utworzono w obwodzie tarnopolskim. Był to PK Przełomy Dniestru, utworzony w 1990 roku, na powierzchni ok. 42 tys. ha.

W roku 1993 w obrębie miasta Lwowa na powierzchni blisko 312 ha utworzono pierwszy w obwodzie Park Krajobrazowy Zniesienie. Kolejne parki krajobrazowe tworzono w roku 1997: Nadsański (19 428 ha) i Beskidy Brzeżne (8536 ha). W roku 2007 na Roztoczu oprócz parku narodowego i rezerwatu przyrodniczego powstał też PK Roztocze Rawskie (19 103 ha). W roku 2013 na terenie 
rejonów Mikołajowa, Przemyślan i Pustomytów przystąpiono do tworzenia Parku Krajobrazowego Horbohirja Stilsko ( 8909 ha). Na koniec 2013 roku obszar objęty ochroną w formie parków krajobrazowych wynosił 56 288,0 ha (ok. 2,6\% obszaru obwodu). Na terenie obwodu lwowskiego utworzono 2 parki narodowe: Jaworowski, powstały w oparciu o wspomniany poligon, oraz Beskidy Brzeżne (1999). Park Narodowy Beskidy Skolskie powstał na bazie istniejących od 1983 roku: Skolskiego Rezerwatu Leśnego i Parków Krajobrazowych Zelemeń oraz Majdan, które utworzono w celu ochrony bukowych oraz jodłowo-bukowych kompleksów leśnych.

Obszary charakteryzujące się krajobrazem naturalnym lub zbliżonym do naturalnego zajmują w obwodzie lwowskim ponad 30\% powierzchni (Program rozwoju... 2013). Do chwili obecnej utworzono wiele obiektów o różnym stopniu ochrony. Przedstawia je tabela 2.

\section{OBSZARY CHRONIONE W STREFIE PRZYGRANICZNEJ}

Województwo lubelskie graniczy z Ukrainą na odcinku $227 \mathrm{~km}(52 \%$ długości granicy polsko-ukraińskiej). $\mathrm{Z}$ tego blisko $1 / 3$ to granica między województwem lubelskim i obwodem lwowskim. Wspomniana wcześniej spójność przyrodnicza pogranicza polsko-ukraińskiego była inspiracją do tworzenia transgranicznych obszarów chronionych. Propozycję utworzenia takich obszarów w oparciu o współpracę polsko-ukraińską przedstawił Instytut Ochrony Środowiska. Jednym ze wskazanych tam obszarów był Transgraniczny Obszar Chroniony Roztocze o powierzchni ok. 200 tys. ha (Krawczuk i in. 1997; Rąkowski 2000). Ze względu na unikalne walory przyrodnicze, krajobrazowe i kulturowe na tym obszarze istniała możliwość utworzenia Międzynarodowego Rezerwatu Biosfery Roztocze. W czerwcu 2011 roku komisja MAB UNESCO zatwierdziła utworzenie Rezerwatu Biosfery Roztocze o powierzchni 74,8 tys. ha na terytorium Ukrainy. W skład RB weszły: Rezerwat Przyrodniczy Roztocze, Jaworowski Narodowy Park Przyrodniczy, Regionalny Park Krajobrazowy Roztocze Rawskie, rezerwat ornitologiczny Janowskie Czaple i uroczysko Niemirów. W 2015 roku złożono wniosek ze strony polskiej o powiększenie Rezerwatu na terytorium Polski i nadanie mu statusu transgranicznego (http://roztoczanskipn.pl). Zasięg proponowanego Transgranicznego Rezerwatu Biosfery przedstawia ryc. 1.

Dokonując analizy ochrony w dokładniejszej skali, dostrzegalne są różnice w podejściu do idei ochrony przyrody, form ochrony, powierzchni obszarów podlegających ochronie prawnej. Szczegółowa analiza rozmieszczenia obszarów chronionych w strefie przygranicznej, poza strefą projektowanego TRB, wskazuje na brak ich ciągłości i kontynuacji po obu stronach granicy. Zestawienia zawarte $\mathrm{w}$ tabeli 3 i 4 odzwierciedlają asymetrię w powierzchni chronionej obu analizowanych regionów. 


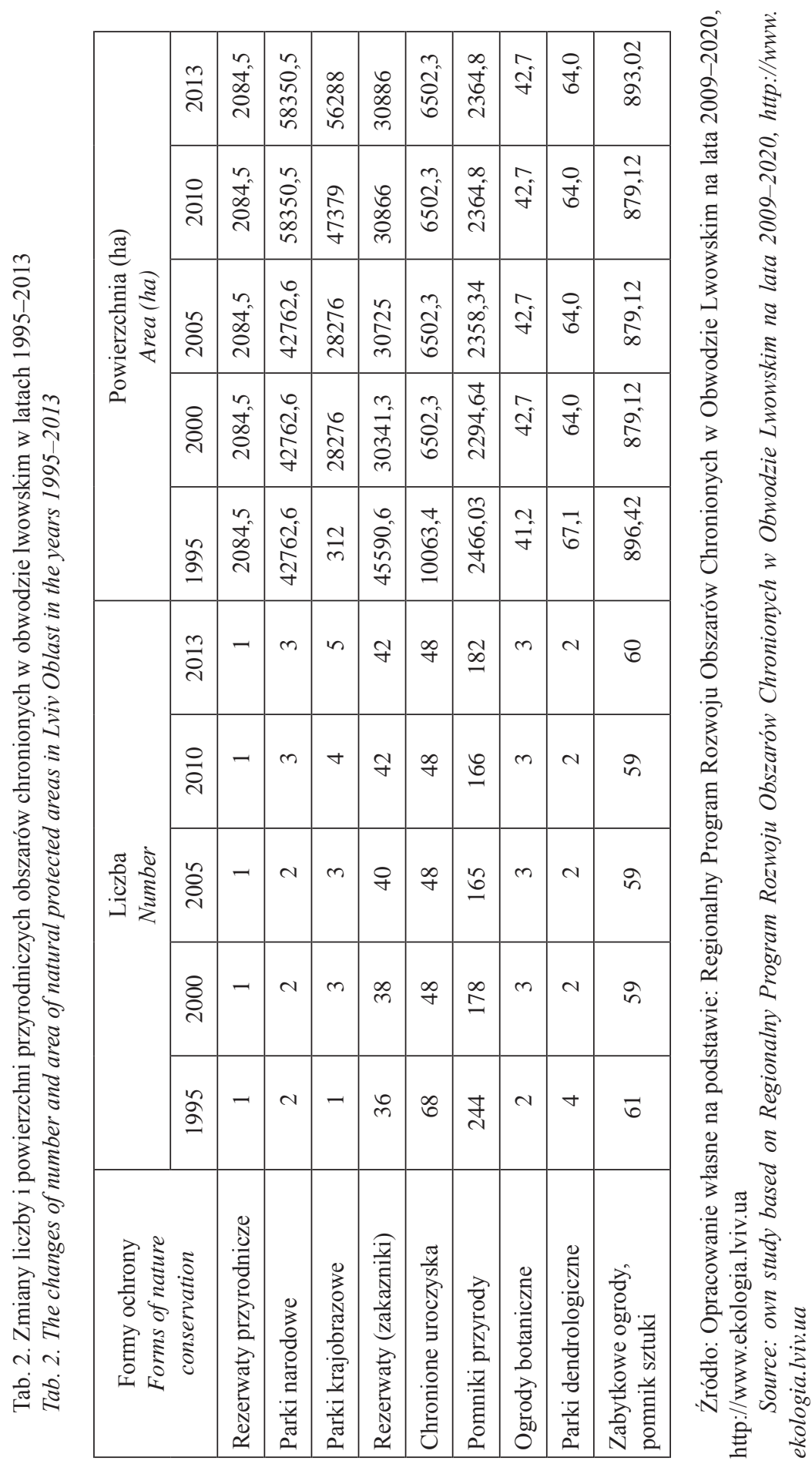




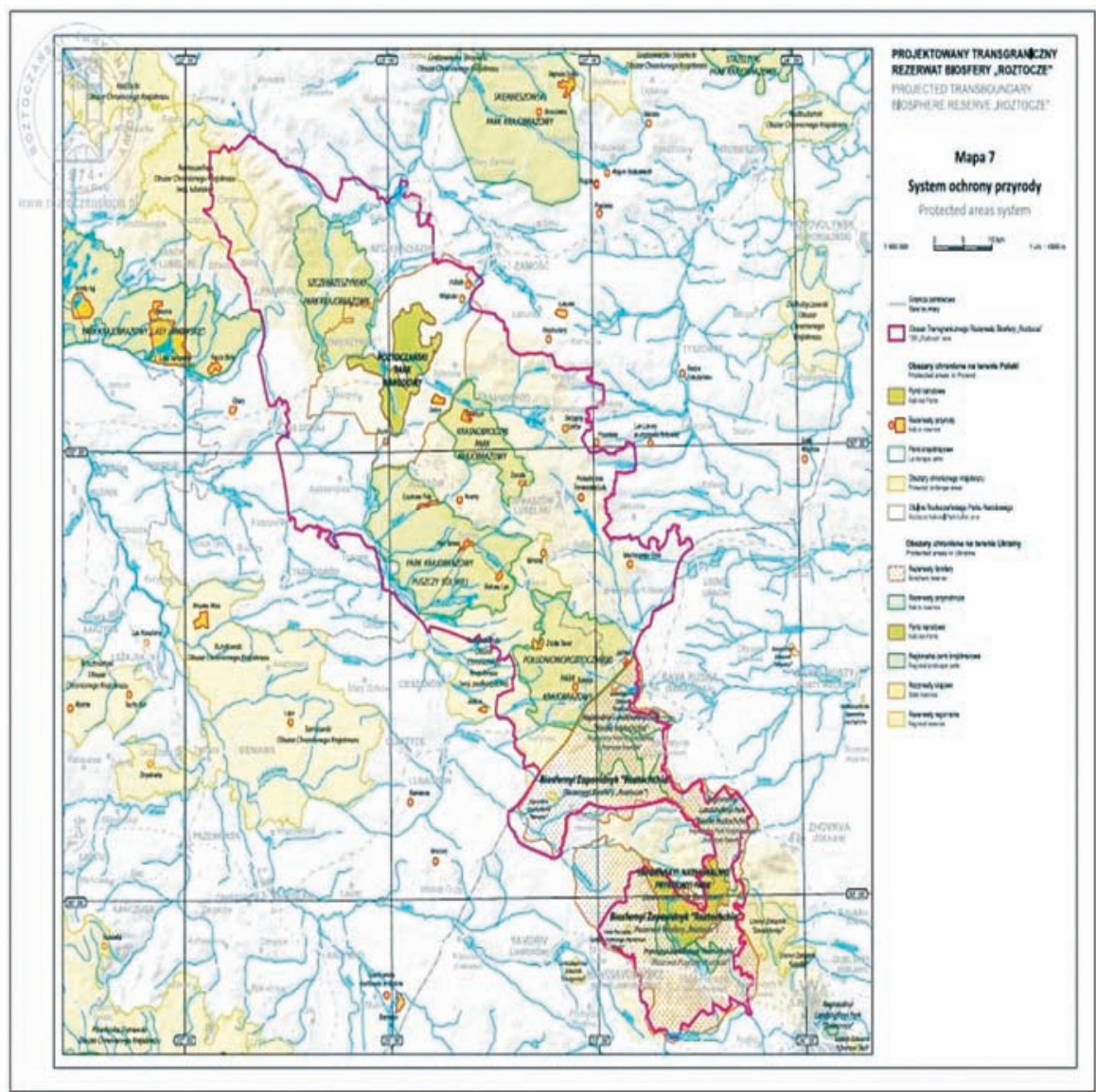

Ryc. 1. Projektowany Transgraniczny Rezerwat Biosfery Roztocze na tle istniejących form ochrony przyrody

Żródło: http://roztoczanskipn.pl/pl/park-na-roztoczu/trb-roztocze

Fig. 1. Projected Transboundary Biosphere Reserve Roztocze against forms of nature protection

Source: http://roztoczanskipn.pl/pl/park-na-roztoczu/trb-roztocze

Po stronie polskiej utworzono 3 rezerwaty przyrody, 12 obszarów Natura 2000, park krajobrazowy i obszar chronionego krajobrazu; po stronie ukraińskiej: rezerwat biosfery, regionalny park krajobrazowy, a także rezerwat o znaczeniu regionalnym.

\section{PODSUMOWANIE}

Pogranicze lubelsko-lwowskie jest obszarem spójnym przyrodniczo, ale kształtowanym po II wojnie światowej przez wiele odmiennych czynników politycznych, historycznych, prawnych, ekonomicznych i społecznych, które wpły- 
Tab. 3. Formy ochrony przyrody w strefie przygranicznej województwa lubelskiego

Tab. 3. Forms of nature protection in the border zone of Lubelskie Voivodeship

\begin{tabular}{|c|c|c|c|}
\hline $\begin{array}{l}\text { Forma ochrony } \\
\text { The form of } \\
\text { conservation }\end{array}$ & $\begin{array}{l}\text { Nazwa } \\
\text { Name }\end{array}$ & $\begin{array}{c}\text { Rok utworzenia } \\
\text { Year of } \\
\text { established }\end{array}$ & $\begin{array}{l}\text { Powierzchnia } \\
\text { całkowita (ha) } \\
\text { Total area (ha) }\end{array}$ \\
\hline \multirow[t]{3}{*}{ Rezerwaty } & Suśle Wzgórza rezerwat faunistyczny & 1995 & 27,11 \\
\hline & Jalinka rezerwat leśny & 2000 & 3,8 \\
\hline & Machnowska Góra rezerwat stepowy & 2003 & 25,30 \\
\hline \multirow[t]{12}{*}{$\begin{array}{c}\text { Obszary } \\
\text { Natura } 2000\end{array}$} & $\begin{array}{c}\text { Obszar Specjalnej Ochrony Ptaków Dolina } \\
\text { Środkowego Bugu PLB060003 }\end{array}$ & 2004 & 28096,55 \\
\hline & $\begin{array}{c}\text { Obszar Specjalnej Ochrony Sie- } \\
\text { dlisk Zachodniowołyńska Dolina Bugu } \\
\text { PLH060035 }\end{array}$ & 2008 & 1556,10 \\
\hline & $\begin{array}{c}\text { Obszar Specjalnej Ochrony Ptaków Dolina } \\
\text { Szyszły PLH060042 }\end{array}$ & 2007 & 2557,21 \\
\hline & $\begin{array}{c}\text { Obszar Specjalnej Ochrony Ptaków Dolina } \\
\text { Sołokii PLB060021 }\end{array}$ & 2007 & 13667,76 \\
\hline & $\begin{array}{l}\text { Obszar Specjalnej Ochrony Ptaków } \\
\text { Roztocze PLB060012 }\end{array}$ & 2007 & 103503,33 \\
\hline & $\begin{array}{c}\text { Obszar Specjalnej Ochrony Siedlisk } \\
\text { Uroczyska Lasów Strzeleckich } \\
\text { PLH060099 }\end{array}$ & 2009 & 3598,64 \\
\hline & $\begin{array}{l}\text { Obszar Specjalnej Ochrony Siedlisk Lasy } \\
\text { Sobiborskie PLH060043 }\end{array}$ & 2008 & 9709,30 \\
\hline & $\begin{array}{l}\text { Obszar Specjalnej Ochrony Siedlisk Lasy } \\
\text { Dołhobyczowskie PLH060103 }\end{array}$ & 2011 & 472,98 \\
\hline & $\begin{array}{c}\text { Obszar Specjalnej Ochrony Siedlisk Suśle } \\
\text { Wzgórza PLH060019 }\end{array}$ & 2008 & 27,23 \\
\hline & $\begin{array}{l}\text { Obszar Specjalnej Ochrony Siedlisk } \\
\text { Tarnoszyn PLH060100 }\end{array}$ & 2011 & 368,09 \\
\hline & $\begin{array}{c}\text { Obszar Specjalnej Ochrony Siedlisk } \\
\text { Uroczyska Roztocza Wschodniego } \\
\text { PLH060093 }\end{array}$ & 2011 & 5809,99 \\
\hline & $\begin{array}{l}\text { Obszar Specjalnej Ochrony Siedlisk Łąki } \\
\text { nad Szyszką PLH060042 }\end{array}$ & 2009 & 981,09 \\
\hline
\end{tabular}


Tab. 3, cd.

\begin{tabular}{|c|c|c|c|}
\hline $\begin{array}{c}\text { Park } \\
\text { krajobrazowy }\end{array}$ & $\begin{array}{c}\text { Południoworoztoczański } \\
\text { Park Krajobrazowy }\end{array}$ & 1991 & 20256,0 \\
\hline $\begin{array}{c}\text { Obszar chronio- } \\
\text { nego krajobrazu }\end{array}$ & $\begin{array}{c}\text { Dołhobyczowski Obszar } \\
\text { Chronionego Krajobrazu }\end{array}$ & 1996 & 7307,50 \\
\hline
\end{tabular}

Źródło: Opracowanie własne na podstawie: Cebrykow i in. 2012, http://natura2000.gdos.gov. pl/natura2000, Rejestr form ochrony przyrody, http://bip.lublin.rdos.gov.pl/rejestr-form-ochronyprzyrody

Source: own study based on: Cebrykow i in. 2012, http://natura2000.gdos.gov.pl/natura2000, Rejestr form ochrony przyrody, http://bip.lublin.rdos.gov.pl/rejestr-form-ochrony-przyrody

Tab. 4. Formy ochrony przyrody w strefie przygranicznej obwodu lwowskiego

Tab. 4. Forms of nature protection in the border zone of Lviv Oblast

\begin{tabular}{|c|c|c|c|}
\hline $\begin{array}{c}\text { Forma ochrony } \\
\text { The form of conservation }\end{array}$ & $\begin{array}{c}\text { Nazwa } \\
\text { Name }\end{array}$ & $\begin{array}{c}\text { Rok utworzenia } \\
\text { Year of } \\
\text { established }\end{array}$ & $\begin{array}{c}\text { Powierzchnia } \\
\text { całkowita (ha) } \\
\text { Total area (ha) }\end{array}$ \\
\hline Rezerwat biosfery & Rezerwat Biosfery Roztocze & 2011 & 74800 \\
\hline $\begin{array}{c}\text { Regionalny park } \\
\text { krajobrazowy }\end{array}$ & $\begin{array}{c}\text { Regionalny Park krajobrazowy } \\
\text { Roztocze Rawskie }\end{array}$ & 2007 & 19103 \\
\hline $\begin{array}{c}\text { Rezerwat (o znaczeniu } \\
\text { regionalnym) }\end{array}$ & Fedorówka & 1984 & 14090 \\
\hline
\end{tabular}

Źródło: Opracowanie własne na podstawie: Protected Planet Report 2014 i Regionalny Program Rozwoju Obszarów Chronionych w Obwodzie Lwowskim na lata 2009-2020, http://www.ekologia. lviv.ua

Source: own study based on: Protected Planet Report 2014 i Regionalny Program Rozwoju Obszarów Chronionych w Obwodzie Lwowskim na lata 2009-2020, http://www.ekologia.lviv.ua

nęły na stan ochrony przyrody. Ochrona przyrody tego obszaru w okresie przedwojennym związana była głównie z działalnością ośrodka naukowego we Lwowie i Ordynacji Zamojskiej na Roztoczu. Po wojnie w Polsce zaistniały większe możliwości rozwoju ochrony dzięki utworzeniu Uniwersytetu Marii Curie-Skłodowskiej w Lublinie, koncentrującego badania przyrodnicze na Lubelszczyźnie. Oprócz ośrodka naukowego, współtworzonego przez Katolicki Uniwersytet Lubelski, Politechnikę Lubelską i Uniwersytet Przyrodniczy, działania na rzecz ochrony kontynuowali społecznicy z licznych organizacji i towarzystw o zasięgu krajowym, regionalnym i lokalnym, a także osoby prywatne. Przyczyniło się to do lepszego rozpoznania walorów przyrodniczych i pozwoliło wskazać obszary wymagające ochrony. W wyniku wstąpienia do Unii Europejskiej powołano wiele nowych obszarów chronionych należących do sieci Natura 2000. 
Strona ukraińska, wykorzystając tradycje badań przyrodniczych w ośrodku lwowskim, włącza się w nurt tworzenia obszarów chronionych, również w strefie przygranicznej, jednak proces ten nie jest jeszcze tak zaawansowany jak w Polsce. Integracja obu systemów ochrony rozpoczęła się od utworzenia obszarów transgranicznych na obszarach o wybitnych walorach przyrodniczych. Te dobre przykłady pozwalają przypuszczać, że w korzystniejszej sytuacji społeczno-ekonomicznej i politycznej łatwiej będzie stworzyć spójny system obszarów chronionych o znaczeniu lokalnym i regionalnym.

\section{SUMMARY}

Lubelskie Voivodeship located on the Polish borderline and on the edge of the European Union is a very important area of development of the integration processes The natural area of cooperation between Poland and Ukraine is to protect nature and the environment. Nature conservation on the Polish-Ukrainian border is an example of successful cooperation of neighboring countries. Despite the differences within the policy of nature conservation, the cooperation brought the establishment of the UNESCO nature reserve. Those differences concern mainly the approach to the idea and forms of conservation in legally protected areas. These differences will be shown on the example of border areas of Lubelskie Voivodeship and Lviv Oblast.

\section{LITERATURA}

Brusak W., 2000: Istorija, suchasnyj stan i perspektyvy rozvytku zapovidnoji spravy na Roztochchi, Visnyk Lvivskoho Universytetu, Seria geografichna, Lviv (Historia, stan obecny i perspektywy rozwoju obszarów chronionych na Roztoczu), Dziennik Uniwersytetu Lwowskiego, Seria Geografia, Wydawnictwo Uniwersytetu Lwowskiego, 237-242.

Cebrykow P., Kałamucka W., Kałamucki K., Meksuła M. W., 2012: Parki krajobrazowe i inne formy ochrony przyrody w województwie lubelskim, Mapa w skali $1: 300$ 000, Kartpol, Lublin.

Denysiuk Z., Stoyko S., 2000: Ekologiczne podstawy utworzenia rezerwatów biosfery na pograniczu Polski i Ukrainy, Chrońmy Przyrodę Ojczystą, 56, nr 1, 18-26.

Herenczuk K., Stoyko S., 1976: Pryrodni parky - nova forma terytorialnoji ochorony pryrody ta jich geografichna meza (Parki przyrodnicze - nowa forma obszarowej ochrony przyrody na Ukrainie oraz ich granica geograficzna), Wyższa Szkoła, Kijów, 3-8.

Krawczuk J., Rąkowski G., Brusak W., Zińko J., 1997: Stvorennia i turystychne vykorystannia miznarodnych pryrodoochoronnych objektiv u Zakhidnij Ukraini. Socialno-ekonomichni i ekologo-geografichni problemy zachidno-ukrainskoho prykordonnia (Tworzenie i turystyczne wykorzystanie międzypaństwowych obszarów chronionych w zachodniej części Ukrainy. Ekonomiczne, społeczne, ekologiczne i geograficzne problemy pogranicza zachodnioukraińskiego), Wydawnictwo Uniwersytetu Lwowskiego, Lwów, 173-191.

Rąkowski G., 2000: Transgraniczne obszary chronione na wschodnim pograniczu Polski: zarys koncepcji, Instytut Ochrony Środowiska, Warszawa.

Simonides E., 2007: Ochrona przyrody, Wydawnictwo Uniwersytetu Warszawskiego, Warszawa.

Stoyko S., 1992: Koncepcija novoji katehoriji ochoronnych terytorij - rehionalnych landshaftnych parkiv ta jich socialno-ekologichne znachennia, [w:] Socialno-ekologichni j ekonomiko-pravo- 
vi aspekty rozvytku zapovidnoji spravy na Ukraini (Koncepcja nowych obszarów chronionych regionalnych parków krajobrazowych oraz ich znaczenie socjalne i ekologiczne, [w:] Socjalne, ekologiczne i prawne aspekty rozwoju ochrony przyrody na Ukrainie), Rachów, 99-101.

Strategia Wspótpracy Transgranicznej Województwa Lubelskiego, Obwodu Lwowskiego, Obwodu Wotyńskiego i Obwodu Brzeskiego na lata 2014-2020, 2014, Kawałko B. (koordynator), Urząd Marszałkowski Województwa Lubelskiego, Lublin.

Szafer W. (red.), 1965: Ochrona przyrody i jej zasobów, Polska Akademia Nauk, Kraków.

Wodziczko A., 1937: Planowanie kraju droga do utrzymania równowagi w przyrodzie, Ochrona Przyrody, R. 17, Kraków, 2-9.

Wachniewska A., 1959: Z historii ochrony przyrody na Roztoczu, Chrońmy Przyrodę Ojczystą, 3, 11-19.

\section{Źródla internetowe}

http://natura2000.gdos.gov.pl/natura2000 dane/pdf [dostęp: październik 2015]

http://roztoczanskipn.pl/files/trb-roztocze/projekt-trb-roztocze/formularz_nominacyjny_TRB

ROZTOCZE.pdf [dostęp: październik 2015]

http://www.iucn.org [dostęp: październik 2015]

http://www.nieznanaukraina.pl/462/parki-narodowe-i-rezerwaty-unesco/ [dostęp: październik 2015]

Program Rozwoju Obszarów Chronionych w Obwodzie Lwowskim na lata 2009-2020 http://www. ekologia.lviv.ua [dostęp: październik 2015]

Protected Planet Report 2014 http://www.iucn.org/about/work/programmes/gpap_home/gpap_biodiversity/gpap_protectedplanet/?18786/Protected-Planet-Report-2014 [dostęp: październik 2015]

Rejestr form ochrony przyrody http://bip.lublin.rdos.gov.pl/rejestr-form-ochrony-przyrody [dostęp: październik 2015]

Ustawa o obszarach chronionych na Ukrainie z dnia 16 czerwca 1992 roku. www.zakonrada.gov.ua [dostęp: październik 2015]

Ustawa o ochronie przyrody z dnia 7 kwietnia 1949 r., Dz.U. $1949 \mathrm{nr}$ 25, poz. 180

Ustawa z dnia 10 marca 1934 r. o ochronie przyrody, Dz.U. $1934 \mathrm{nr}$ 31, poz. 274

Ustawa z dnia 16 kwietnia 2004 r. o ochronie przyrody, Dz.U. 2004 nr 92, poz. 880

Ustawa z dnia 16 października 1991 r. o ochronie przyrody, Dz.U. 1991 nr 114, poz. 492

Wniosek nominacyjny Transgranicznego Rezerwatu Biosfery Roztocze www.stat.gov.pl [dostęp: październik 2015] 